\title{
EVALUASI SEGREGASI TRANSGRESIFQUANTITATIVE TRAIT LOCI (QTL) PADA TANAMAN PADI VARIETAS UNGGUL NASIONAL YANG DIGOGOORGANIKKAN
}

\author{
Rani Yosilia, Saiful Hikam \& Paul B Timotiwu \\ Jurusan Agroteknologi, Fakultas Pertanian, Universitas Lampung, \\ Jl.Prof. Soemantri Brodjonegoro, No.1, Bandar Lampung 35145 \\ E-mail:rani.yosilia@gmail.com
}

\begin{abstract}
ABSTRAK
Penelitian bertujuan untuk (1) menghitung besarnya ragam genetik dan heritabilitas broad-sense pada padi-padi tersebut; (2) mendapatkan varietas yang mampu digunakan sebagai tetua perakitan padi inbrida dan hibrida; (3) mendapatkan korelasi antar peubah yang mampu meningkatkan produksi sekaligus sebagai peubah pada seleksi tidak langsung. Penelitian disusun menggunakan rancangan perlakuan kuasi RTS (Rancangan Teracak Sempurna) karena dalam penelitian ini tidak memungkinkan untuk dilakukan pengulangan kelompok tetapi ulangan berada di dalam satu kelompok yang sama. Masing-masing kelompok ulangan terdiri dari 9 sampel tanaman yang dibagi menjadi 3 ulangan dan masing-masing ulangan terdapat 3 tanaman.Selanjutnya dilakukan analisis ragam, data pengamatan diuji dengan uji Bartlett dan Levene untuk kehomogenan ragam.Bila hasil analisis uji pada analisis ragam nyata pada $\mathrm{P} \leq 0,01$ atau 0,05 maka dilakukan pemeringkatan nilai tengah dengan uji Beda Nyata Jujur (BNJ).Pengujian dan analisis data menggunakan software Statistic Analysis System (SAS) 9.1 for windows. Besarnya ragam genetik dan heritabilitas broad-sense diduga berdasarkankuadrat nilai tengah (KNT) harapan pada analisis ragam dan rancangan percobaan.Hasil penelitian menunjukkan bahwa (1) semua peubah yang diamati mampu memberikan nilai ragam genetik dan heritabilitas broad-sense.(2) Varietas Sarinah-jumlahbulir dan Sarinah-jumlahanakan dapat dijadikan sebagai tetua untuk perakitan padi inbrida dan hibrida; (3) Jumlah bulir total berkorelasi dengan peningkatan produksi sehingga dapat dijadikan sebagai peubah pada seleksi tidak langsung.
\end{abstract}

Kata kunci: gogo-organik, heritabilitas broad-sense, quantitative trait loci, ragamgenetik, segregasi transgresif

\section{PENDAHULUAN}

Indonesia merupakan salah satu negara dengan beras sebagai bahan makanan pokoknya. Untuk meningkatkan produktivitas padi, pemerintah menggencarkan program intensifikasi dan ekstensifikasi pertanian. Selama ini upaya peningkatan padi masih difokuskan pada lahan padi sawah yang tingkat produksinya masih belum memenuhi kebutuhan pangan nasional (Rahayu dan Harjoso, 2010). Oleh sebab itu pengembangan produksi padi di lahan tadah hujan (gogo) perlu mendapatkan perhatian serius. Rata-rata produktivitas padi gogo adalah $2,56 \mathrm{t} \mathrm{ha}{ }^{1}$, jauh dibawah produktivitas padi sawah yakni $4,57 \mathrm{t} \mathrm{ha}^{-1}$ (Mulyani, 2006).

Untuk meningkatkan produktivitas lahan kering, terutama sifat fisik dan kimia tanah maka dapat ditempuh dengan cara penambahan bahan organik. Menurut Barus (2012), bahan organik memiliki peran penting dalam menentukan kemampuan tanah untuk mendukung tanaman. Jika kadar bahan organik menurun, maka kemampuan tanah yang mendukung produktivitas tanaman juga akan menurun.

Guna mendukung produktivitas padi, maka dilakukan pemuliaan tanaman melalui analisis QTL. Analisis QTL membuktikan adanya gen yang berperan didalam segregasi transgresif. Segregasi transgresif didefinisikan sebagai tampilan zuriat self yang jauh lebih baik daripada kedua tetuanya. Padi segregan transgresif memiliki beberapa keunggulan diantaranya: berumur cepat, jumlah bulir yang banyak, tahan terhadap tanah podsolik merah kuning (PMK), dan tahan terhadap hama dan penyakit endemik seperti blas Pyricularia dan hawar daun Xanthomonas (Hikam, 2011).

Penelitian sebelumnya dilakukan di Way Jepara, Lampung Timur ( sawah tadah hujan), Tulang Bawang Barat ( sawah irigasi), dan di Bandar Lampung ( sawah baru ). Segregasi dapat terjadi apabila suatu varietas tertentu ditanam pada kondisi lingkungan yang suboptimum. Oleh karena itu pada penelitian kali ini dilakukan pada lahan darat (gogo) yang diberikan tambahan pupuk organik ( kotoran sapi ). 


\section{BAHAN DAN METODE}

Penelitian ini bertempat di Politeknik Negeri Lampung dan Laboratorium Benih Fakultas Pertanian, Universitas Lampung. Penelitian ini berlangsung dari bulan Desember 2012 sampai April 2013.

Penelitiandisusun menggunakan rancangan perlakuan kuasi RTS (Rancangan Teracak Sempurna) karena dalam penelitian ini tidak memungkinkan untuk dilakukan pengulangan kelompok tetapi ulangan berada di dalam satu kelompok yang sama. Masing-masing kelompok ulangan terdiri dari 9 sampel tanaman yang dibagi menjadi 3 ulangan dan masing-masing ulangan terdapat 3 tanaman. Selanjutnya dilakukan analisis ragam, data pengamatan diuji dengan uji Bartlett dan Levene untuk kehomogenan ragam.Bila hasil analisis uji pada analisis ragam nyata pada $\mathrm{P} \leq 0,01$ atau 0,05 maka dilakukan pemeringkatan nilai tengah dengan uji Beda Nyata Jujur (BNJ). Pengujian dan analisis data menggunakan software Statistic Analysis System (SAS) 9.1 for windows. Besarnya ragam genetik dan heritabilitas broad-sense diduga berdasarkan kuadrat nilai tengah (KNT) harapan pada analisis ragamberdasarkan Hallauer dan Miranda, 1986 dalam Hikam (2010).

Lahan terlebih dahulu diolah menggunakan bajak. Kemudian dibuat bedengan untuk tiap varietas seluas 2 x 1 meter.Antarbedengandibuat saluran sedalam $20 \mathrm{~cm}$ yang berfungsi sebagai saluran drainase.Buat tugal sedalam 5 cmdengan jarak tanam $25 \times 25 \mathrm{~cm}$, masukkan benih padi sebanyak 2 butir/lubang. Dilakukan pemupukan sebanyak dua kali, pemupukan pertama menggunakan pupuk kandang sapi sebanyak $5 \mathrm{t} \mathrm{ha}^{-1}$ yang diberikan saat pengolahan tanah. Pemupukan kedua diberikan setelah 3 minggu setelah tanam (MST) dengan dosis $5 \mathrm{t} \mathrm{ha}^{-1}$ diberikan dengan cara ditaburkan disekitar tanaman padi. Pengendalian hama dan penyakit serta gulma dilakukan dengan cara manual.Penetapan sampel dilakukan pada saat masa vegetatif.Kriteria siap panen adalah daun bendera dan $90 \%$ bulir padi telah menguning dan butir gabah terasa keras bila ditekan.Padi yang telah dipanen kemudian dikeringkan dengan cara dijemur selama beberapa hari hingga kadar air mencapai $14 \%$. Kemudian benih yang telah dirontokkan dari malainya selanjutnya dilakukan pengamatan di laboratorium.

Adapun variabel pengamatan dalam penelitian ini adalah: tinggi tanaman, jumlah anakan per rumpun, umur berbunga, jumlah anakan produktif per rumpun; jumlah gabah total per rumpun, jumlah gabah isi per rumpun, jumlah gabah hampa per rumpun, bobot gabah isi per rumpun; Bobot gabah hampa per rumpun; Bobot kering malai per rumpun, bobot 100 butir isi dan produksi per meter.

\section{HASILDAN PEMBAHASAN}

Hasil penelitian menunjukan bahwa tinggi tanaman dan jumlah anakan total bervariasi sangat nyata (Tabel 1). Nilai koefisien keragaman (KK) pada tinggi tanaman dan jumlah anakan total berturut-turut sebesar 5,70\% dan $19,71 \%$. Nilai koefesien keragaman (KK) menunjukkan tingkat kepercayaan terhadap data.Semakin kecil nilai KK semakin homogen data yang diperoleh dan semakin baik analisis yang dilakukan.Menurut Hikam (2003) dalam Saputri (2012), Nilai KK> 25,6\% menunjukkan lingkungan berpengaruh terhadap kinerja genetik sehingga tidak dapat diabaikan dan harus diseleksi ulang. Koefisien keragaman $<25,6 \%$ menunjukkan bahwa pengaruh genetik lebih besar daripada pengaruh lingkungan dan seluruh tampilan fenotipe merupakan hasil kerja genetik, dengan demikian pengaruh lingkungan dapat diabaikan.

Keragaman yang tinggi pada karakter jumlah anakan total sejalan dengan hasil evaluasi plasma nutfah padi yang tersegregasi transgresif yang dilakukan oleh Suprayogi (2011) dan Suwantike (2011) serta Ramadhana (2013) yang menunjukkan adanya keragaman pada jumlah anakan total yang < 25,6 \%. Hal ini menunjukkan bahwa karakter vegetatif cukup konsisten dan lebih banyak dipengaruhi oleh faktor genetis dibanding faktor lingkungan.

Berdasar hasil penelitian diketahui bahwa jumlah bulir hampa berbeda nyata, sedangkan jumlah anakan

Tabel 1. Rekapitulasi kuadrat nilai tengah pada varietas untuk peubah vegetatif

\begin{tabular}{lcll}
\hline Sumber keragaman & $\mathrm{db}$ & Tinggi tanaman & Jumlah anakan total \\
\hline Entri & 9 & $281,93^{* *}$ & $55,61^{* *}$ \\
Galat & 20 & 19,34 & 12,97 \\
\hline KK $(\%)$ & & 5,70 & 19,71 \\
Xbar & & 77,18 & 18,00 \\
\hline
\end{tabular}

Keterangan: $*$ dan $* *$ berbeda pada $\mathrm{P} \leq 0,05 \mathrm{P} \leq 0,01$ 
produktif, jumlah anakan non produktif, jumlah malai, bobot kering malai, bobot bulir isi, bobot bulir hampa, bobot bulir total, bobot 100 butir, jumlah bulir isi, jumlah bulir total, jumlah bulir per malai, produksi per $\mathrm{m}^{2}$ berbeda sangat nyata antar kesepuluh varietas yang dievaluasi (Tabel 2). Kecuali jumlah anakan produktif, bobot bulir hampa dan bobot 100 butir isi, semua karakter generatif dan komponen hasil memiliki nilai KK > 25,6\%. Dengan demikian karakter yang memiliki keragaman $<25,6 \%$ berpotensi untuk dimanfaatkan dalam program perbaikan bahan tanaman, yakni jumlah anakan produktif dan bobot 100 bulir isi.

Berdasarkan analisis peringkat pada varietas terlihat bahwa terdapat 3 varietas yang berada di peringkat pertama yaitu Sarinah-jumlahanakan, Sarinahjumlahbulir, Ciherang-jumlahanakan (Tabel 3). Apabila dilihat dari standar komersial yang digunakan yaitu varietas Ciherang maka Sarinah-jumlahbulir memiliki produksi yang lebih tinggi dibandingkan Ciherang, sehingga Sarinah-jumlahbulir dapat digunakan sebagai salah satu tetua untuk perbaikan dan peningkatan produksi beras nasional.Namun apabila kita cermati Sarinah-jumlahanakan pula memiliki potensi sebagai salah satu tetua untuk perbaikan dan peningkatan produksi beras nasional. Hal ini terlihat dari Sarinahjumlahanakan memiliki jumlah anakan produktif terbanyak diantara varietas yang ditanam yakni sebanyak 25 anakan dan hampir tidak memiliki anakan non produktif, selain itu pula Sarinah-jumlahanakan memiliki jumlah bulir hampa yang cukup tinggi. Apabila kita mampu memperbaiki teknik budidaya dengan penambahan pupuk dan air maka diduga produksi per $\mathrm{m}^{2}$ Sarinah-jumlahanakan akan meningkat dan mampu menandingi Sarinah-jumlahbulir yang dalam hal ini pula memudahkan peneliti untuk melakukan seleksi tidak langsung.

Nilai koefesien keragaman genetik (KKg) menunjukkan tingkat kepercayaan terhadap $\sigma^{2} \mathrm{~g}$. Semakin kecil nilai KKg semakin homogen data yang diperoleh dan semakin baik analisis $\sigma^{2} \mathrm{~g}$ yang dilakukan. Menurut Hikam (2010) dikutip oleh Suwantike (2011), pada $\mathrm{KKg}<5 \%$ menunjukkan bahwa pengaruh genetik lebih besar dari pengaruh lingkungan, seluruh tampilan fenotipik merupakan hasil kerja genetik dan pengaruh lingkungan dapat diabaikan.Nilai KKg yang baik pada kondisi ideal berkisar antara $5-10 \%$. Nilai $\mathrm{KKg} \leq 10 \%$ dianggap takbias yang berarti terpakainya kinerja fenotipe sebagai penduga genotipe dengan lingkungan tidak dapat diabaikan.

Dari hasil penelitian ini pada Tabel4, karakter vegetatif yakni jumlah anakan total, dan karakter generatif seperti jumlah anakan produktif, jumlah anakan non produktif, jumlah malai, bobot kering malai, bobot bulir hampa, bobot bulir total, jumlah bulir isi, jumlah bulir hampa dan jumlah bulir total memiliki nilai ragam genetik dan heritabilitas yang rendah ( $\geq 1 \mathrm{~GB}$ ). Selain itu terdapat beberapa variabel yang nilai $\mathrm{KKg}$ nya juga tinggi $(>10 \%)$ yaitu bobot kering malai, bobot bulir hampa, bobot bulir total, jumlah bulir isi dan jumlah bulir hampa. Hal ini berarti kelima karakter ini kurang baik untuk digunakan sebagai kriteria seleksi. Sedangkan untuk karakter vegetatif tinggi tanaman, dan karakter generatif serta komponen hasil yakni bobot bulir isi, bobot 100 bulir isi, jumlah bulir per malai dan produksi per $\mathrm{m}^{2}$ mempunyai nilai ragam genetik dan heritabilitas yang tinggi ( $\geq 2 \mathrm{~GB})$ dan nilai KKG yang cukup variatif $(8,33 \%-89,93 \%)$, hal ini berarti karakter seperti bobot 100 bulir isi cukup baik digunakan sebagai salah satu karakter dalam proses seleksi untuk memilih varietas padi yang berdaya hasil tinggi. Khusus untuk variabel jumlah anakan non produktif yang memiliki nilai $\mathrm{KKg}>100 \%$ maka variabel ini dapat diabaikan dan tidak menjadi salah satu variabel yang digunakan sebagai seleksi.

Berdasarkan nilai korelasi terlihat bahwa tidak ada karakter vegetatif yang menunjukkan korelasi dengan peningkatan produksi (Tabel 5). Oleh sebab itu dalam penelitian kali ini karakter vegetatif tidak dapat digunakan sebagai kriteria seleksi.Peubah yang memiliki korelasi nyata terhadap peubah yang menggambarkan produksi yaitu jumlah bulir total. Peubah yang berkorelasi dengan jumlah bulir total adalah jumlah bulir isi, bobot bulir total, bobot 100 bulirisi. Menurut Bahar dan Zen (1999), korelasi positif dan tinggi antara karakter tanaman dapat dijadikan acuan untuk melakukan seleksi serentak lebih dari satu karakter, terutama terhadap karakter yang mempunyai nilai heritabilitas tinggi. Hal tersebut menunjukkan bahwa semakin berat bobot bulir isi, maka karakter lainnya akan semakin baik sehingga seleksi serentak dapat dilakukan dengan lebih mudah.

Menurut Hikam dan Yuliadi (1996) dalam Hikam (2010), agar peubah sesuai dengan seleksi tidak langsung harus memenuhi kriteria yaitu (1) berkorelasi positif nyata dengan produktivitas; (2) mempunyai nilai $\sigma^{2} \mathrm{~g} \mathrm{dan}^{2}{ }_{\mathrm{BS}}$ yang > GB masing-masing; (3) mudah diukur dengan alat ukur yang sederhana; dan (4) dapat diukur pada masa vegetatif, tidak perlu menunggu sampai panen, tetapi harus logis. Gambar 1 menunjukkan bahwa yang dapat digunakan sebagai peubah seleksi tidak langsung 
Tabel 2.Rekapitulasi kuadrat nilai tengah pada varietas untuk peubah generatif

\begin{tabular}{|c|c|c|c|c|c|c|c|c|c|c|c|c|c|c|}
\hline $\begin{array}{l}\text { Sumber } \\
\text { Keragaman }\end{array}$ & $\mathrm{db}$ & $\begin{array}{l}\text { Jumlah } \\
\text { anakan } \\
\text { produktif }\end{array}$ & $\begin{array}{l}\text { Jumlah } \\
\text { anakan non } \\
\text { produktif }\end{array}$ & $\begin{array}{l}\text { Jumlah } \\
\text { malai }\end{array}$ & $\begin{array}{l}\text { Bobot } \\
\text { kering } \\
\text { malai }\end{array}$ & $\begin{array}{l}\text { Bobot } \\
\text { bulir } \\
\text { isi }\end{array}$ & $\begin{array}{l}\text { Bobot } \\
\text { bulir } \\
\text { hampa } \\
\end{array}$ & $\begin{array}{l}\text { Bobot } \\
\text { bulir } \\
\text { total }\end{array}$ & $\begin{array}{l}\text { Bobot } \\
100 \\
\text { Butir } \\
\end{array}$ & $\begin{array}{l}\text { Jumlah } \\
\text { bulir } \\
\text { Isi }\end{array}$ & $\begin{array}{l}\text { Jumlah } \\
\text { bulir } \\
\text { hampa }\end{array}$ & $\begin{array}{l}\text { Jumlah } \\
\text { bulir } \\
\text { total }\end{array}$ & $\begin{array}{l}\text { Jumlah } \\
\text { bulir } \\
\text { per malai }\end{array}$ & $\begin{array}{l}\text { Produksi } \\
\text { per m }\end{array}$ \\
\hline Entri & 9 & $51,99 * *$ & $17,54^{* *}$ & $102,87 * *$ & $1,01 * *$ & $47,24^{* *}$ & $6,42^{* *}$ & $58,69 * *$ & $0,12^{* *}$ & $75371,94 * *$ & $238976,65 *$ & 337708,30* & $3519,76^{* *}$ & $106989,82 * *$ \\
\hline Galat & 20 & 13,30 & 4,60 & 25,37 & 0,21 & 5,62 & 1,10 & 9,40 & 0,02 & 11259,23 & 92086,77 & 109802,40 & 383,17 & 19675,24 \\
\hline KK (\%) & & 21,79 & 123,74 & 27,78 & 30,52 & 36,88 & 24,23 & 28,76 & 5,50 & 36,61 & 38,53 & 30,76 & 29,93 & 51,78 \\
\hline Xbar & & 17 & 2 & 19 & 1,52 & 6,43 & 4,33 & 10,66 & 2,24 & 290 & 788 & 1077 & 65 & 270,87 \\
\hline
\end{tabular}

Tabel 3. Peringkat varietas berdasarkan $\mathrm{BNJ}_{0,05}$

\begin{tabular}{|c|c|c|c|c|c|c|c|c|c|c|c|c|c|c|c|c|c|}
\hline Varietas & $\begin{array}{l}\text { Jumlah } \\
\text { anakan } \\
\text { total }\end{array}$ & $\begin{array}{l}\text { Tinggi } \\
\text { Tanaman }\end{array}$ & $\begin{array}{l}\text { Jumlah } \\
\text { anakan } \\
\text { produktif }\end{array}$ & $\begin{array}{l}\text { Jumlah } \\
\text { anakan non } \\
\text { produktif }\end{array}$ & $\begin{array}{l}\text { Jumlah } \\
\text { malai }\end{array}$ & $\begin{array}{l}\text { Bobot } \\
\text { kering } \\
\text { malai }\end{array}$ & $\begin{array}{l}\text { Bobot } \\
\text { bulir } \\
\text { isi }\end{array}$ & $\begin{array}{l}\text { Bobot } \\
\text { bulir } \\
\text { hampa }\end{array}$ & $\begin{array}{l}\text { Bobot } \\
\text { bulir } \\
\text { total }\end{array}$ & $\begin{array}{l}\text { Bobot } \\
100 \\
\text { Butir }\end{array}$ & $\begin{array}{l}\text { Jumlah } \\
\text { bulir } \\
\text { isi }\end{array}$ & $\begin{array}{l}\text { Jumlah } \\
\text { bulir } \\
\text { hampa }\end{array}$ & $\begin{array}{l}\text { Jumlah } \\
\text { bulir } \\
\text { total }\end{array}$ & $\begin{array}{l}\text { Jumlah } \\
\text { bulir } \\
\text { per malai }\end{array}$ & $\begin{array}{l}\text { Produksi } \\
\text { per } \mathrm{m}^{2}\end{array}$ & $\begin{array}{l}\text { Jumlah } \\
\text { huruf a }\end{array}$ & Ranking \\
\hline Sarinah-Tgi & $16,00 \mathrm{a}$ & 79,83 & $16,00 \mathrm{a}$ & $0,00 \mathrm{a}$ & $18,50 \mathrm{a}$ & $2,15 \mathrm{a}$ & 1,66 & 5,53 & 7,187 & $2,35 \mathrm{a}$ & 69,67 & 653,80 & $723,5 \mathrm{a}$ & 39,24 & 34,8 & 8 & 2 \\
\hline Sarinah-Jan & 26,33 a & 76,22 & 25,44 a & $0,78 \mathrm{a}$ & $25,22 \mathrm{a}$ & $2,13 \mathrm{a}$ & 10,44 a & 5,05 & $15,49 a$ & 2,19 & 507,00 a & 887,90 & 1394,90 a & 55,68 & $313,00 \mathrm{a}$ & 10 & 1 \\
\hline Sarinah-Jbu & 21,67 a & 83,00 & 19,33 a & 2,45 & 21,89 a & $1,91 \mathrm{a}$ & 13,59 a & 5,02 & 18,62 a & $2,67 \mathrm{a}$ & 507,3 a & 742,40 & 1249,80 a & 63,42 & $652,40 \mathrm{a}$ & 10 & 1 \\
\hline IR64-Tgi & 22,00 a & 96,89 a & 20,78 a & $1,22 \mathrm{a}$ & $30,11 \mathrm{a}$ & $2,19 \mathrm{a}$ & 3,63 & 4,56 & 8,20 & 2,09 & 188,44 & 1116,70 & 1305,10 a & 43,53 & 174,50 & 7 & 3 \\
\hline IR64-Jan & 15,33 & 68,39 & $15,00 \mathrm{a}$ & $0,17 \mathrm{a}$ & $18,11 \mathrm{a}$ & $1,22 \mathrm{a}$ & 4,76 & 3,95 & 8,70 & 2,20 & 223,5 a & 562,20 & $785,70 \mathrm{a}$ & 39,18 & 222,10 & 6 & 4 \\
\hline IR64-Jbu & $18,00 \mathrm{a}$ & 60,33 & $17,72 \mathrm{a}$ & $0,17 \mathrm{a}$ & $18,56 \mathrm{a}$ & $1,13 \mathrm{a}$ & 3,14 & $1,31 \mathrm{a}$ & 4,44 & 2,07 & 163,39 & $337,70 \mathrm{a}$ & 501,10 & 25,94 & 105,80 & 7 & 3 \\
\hline Ciliwung-Jan & 14,67 & 72,39 & 11,50 & 3,11 & 11,50 & 0,04 & $6,96 \mathrm{a}$ & 6,15 & 13,11 a & 2,07 & 355,10 a & 1239,10 & 1594,20 a & 140,29 a & $252,70 \mathrm{a}$ & 6 & 4 \\
\hline Ciliwung-Jbu & 12,67 & 79,78 & 13,78 & $0,67 \mathrm{a}$ & 12,67 & 0,75 & 5,96 & 5,35 & 10,35 a & $2,34 \mathrm{a}$ & $256,00 \mathrm{a}$ & 903,30 & 1159,30 a & 96,38 a & 286,20 a & 7 & 3 \\
\hline Ciherang-Jan & 15,00 & 81,00 & 14,67 a & $0,56 \mathrm{a}$ & 15,22 & $1,86 \mathrm{a}$ & 10,86 a & $2,71 \mathrm{a}$ & 13,58 a & $2,42 \mathrm{a}$ & $465,20 a$ & 494,40 & 959,70 a & 62,55 & $521,40 \mathrm{a}$ & 10 & 1 \\
\hline Ciherang-Jbu & $21,00 \mathrm{a}$ & 74,00 & 12,78 & 8,00 & 13,22 & 0,85 & 3,26 & 3,63 & 6,90 & 2,06 & 161,89 & 937,90 & 1099,80 a & 87,26 a & 145,90 & 3 & 5 \\
\hline Standar komersil & & $107-115$ & $14-17$ & - & - & - & - & - & - & 2,80 & - & - & - & - & 600,00 & & \\
\hline BNJ & 10,41 & 12,71 & 10,54 & 6,20 & 14,56 & 1,34 & 6,85 & 3,032 & 8,86 & 0,36 & 306,79 & 877,39 & 958,08 & 56,60 & 405,56 & & \\
\hline
\end{tabular}

Keterangan: Tgi = tinggi tanaman, Jan = jumlah anakan, dan Jbu = jumlah bulir. 
Tabel 4. Nilai dugaan ragam genetik, galat baku ragam genetik, koefisien keragaman genetik, heritabilitas, galat baku heritabilitas karakter vegetatif dan generatif

\begin{tabular}{lrlrlr}
\hline \multicolumn{1}{c}{ Variabel } & $\sigma^{2} \mathrm{~g}$ & $\pm(\mathrm{GB}) \sigma^{2} \mathrm{~g}$ & $\mathrm{~h}_{\mathrm{BS}}^{2}$ & $\pm \mathrm{GB} \mathrm{h}^{2}{ }_{\mathrm{BS}}$ & $\mathrm{KKg}(\%)$ \\
\hline Jumlah anakan produktif & 12,89 & $\pm 7,51^{*}$ & 74,42 & $\pm 43,33^{*}$ & 20,29 \\
Jumlah anakan non produktif & 4,31 & $\pm 2,54^{*}$ & 73,78 & $\pm 43,37^{*}$ & 133,52 \\
Jumlah anakan total & 14,22 & $\pm 8,01^{*}$ & 76,68 & $\pm 43,22^{*}$ & 19,70 \\
Tinggi tanaman & 87,53 & $\pm 40,12^{* *}$ & 93,14 & $\pm 42,69^{* *}$ & 12,05 \\
Jumlah malai & 25,84 & $\pm 14,84^{*}$ & 75,34 & $\pm 43,28^{*}$ & 24,90 \\
Bobot kering malai & 0,27 & $\pm 0,15^{*}$ & 78,78 & $\pm 43,12^{*}$ & 29,57 \\
Bobot bulir isi & 13,87 & $\pm 6,74^{* *}$ & 88,11 & $\pm 42,79^{* *}$ & 49,84 \\
Bobot bulir hampa & 1,77 & $\pm 0,92^{*}$ & 82,86 & $\pm 42,95^{*}$ & 27,05 \\
Bobot bulir total & 16,43 & $\pm 8,39^{*}$ & 83,99 & $\pm 42,91^{*}$ & 32,92 \\
Bobot 100 bulir isi & 0,03 & $\pm 0,01^{* *}$ & 87,13 & $\pm 42,82^{* *}$ & 8,33 \\
Jumlah bulir isi & 21370,90 & $\pm 10772,50^{*}$ & 85,06 & $\pm 42,88^{*}$ & 44,32 \\
Jumlah bulir hampa & 48963,30 & $\pm 35204,98^{*}$ & 61,47 & $\pm 44,19^{*}$ & 26,59 \\
Jumlah bulir total & 75968,60 & $\pm 49252,02^{*}$ & 67,49 & $\pm 43,75^{*}$ & 23,72 \\
Jumlah bulir per malai & 1045,50 & $\pm 501,76^{* *}$ & 89,11 & $\pm 42,77^{* *}$ & 50,16 \\
Produksi per ${ }^{2}$ & 86688,30 & $\pm 36707,36^{* *}$ & 92,75 & $\pm 39,27^{* *}$ & 89,93 \\
\hline Kerangan
\end{tabular}

Keterangan: $\sigma^{2} \mathrm{~g}=$ ragam genetik, $\mathrm{h}^{2}{ }_{\mathrm{BS}}=$ heritabilitas broad-sense, $\mathrm{KKg}=$ koefisien keragaman genetik, $\mathrm{GB} \sigma^{2} \mathrm{~g}=$ galat baku ragam genetik, $\mathrm{GB} \mathrm{h}^{2}{ }_{\mathrm{BS}}=$ galat baku heritabilitas broad-sense, $*$ = berbeda dari nol $\left(\sigma^{2} \mathrm{~g}\right.$ atau $\left.\mathrm{h}_{\mathrm{BS}}^{2} \geq 1 \mathrm{~GB}\right)$, dan $* *=$ berbeda dari nol $\left(\sigma^{2} \mathrm{~g}\right.$ atau $\left.\mathrm{h}_{\mathrm{BS}}^{2} \geq 2 \mathrm{~GB}\right)$.

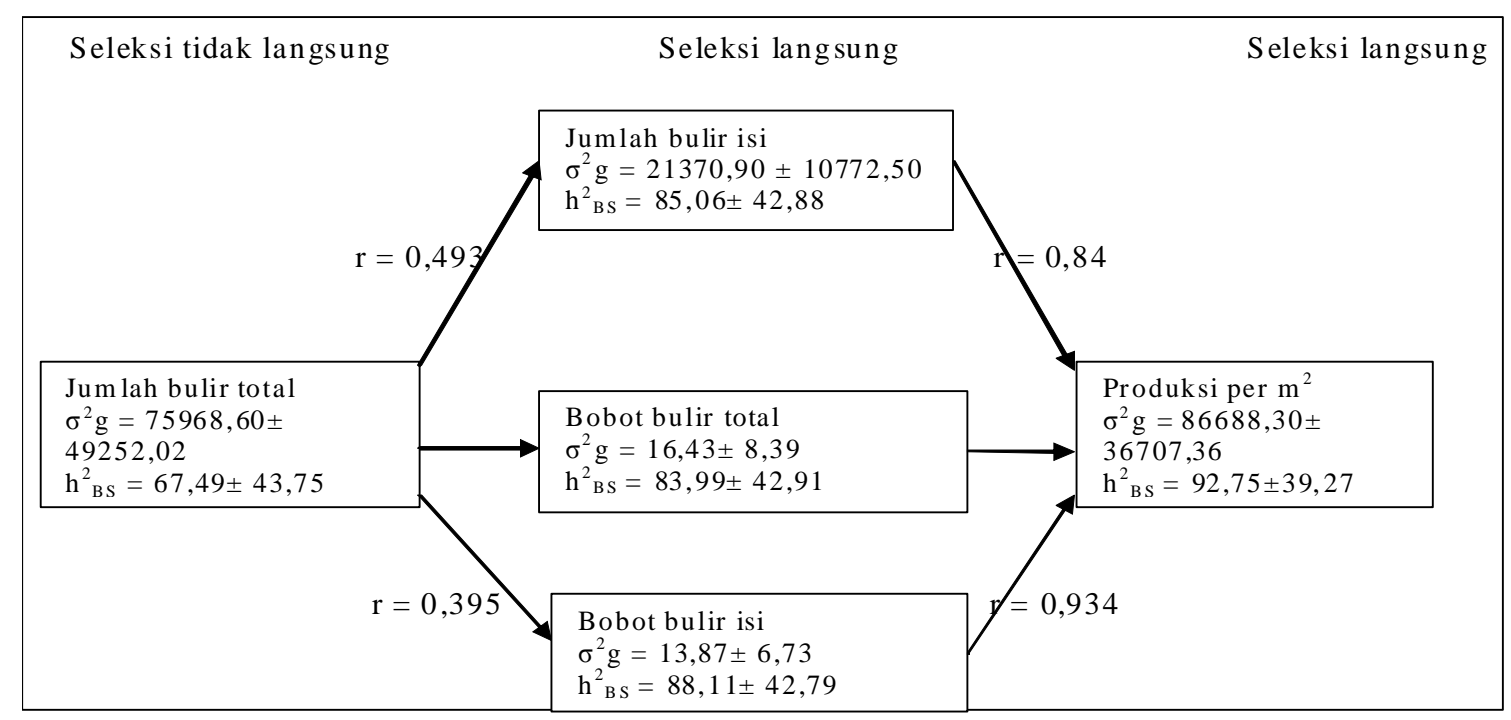

Gambar 1. Penetapan peubah untuk seleksi tidak langsung yang berperan terhadap seleksi langsung menggunakan nilai $\sigma^{2} \mathrm{~g}, \mathrm{~h}_{\mathrm{BS}}^{2}$, dan $\mathrm{r}$ varietas yang memenuhi persyaratan $: \mathrm{r}=* * * ; \sigma^{2} \mathrm{~g}=* / * * ; \mathrm{h}_{\mathrm{BS}}^{2}=* / * *$. 


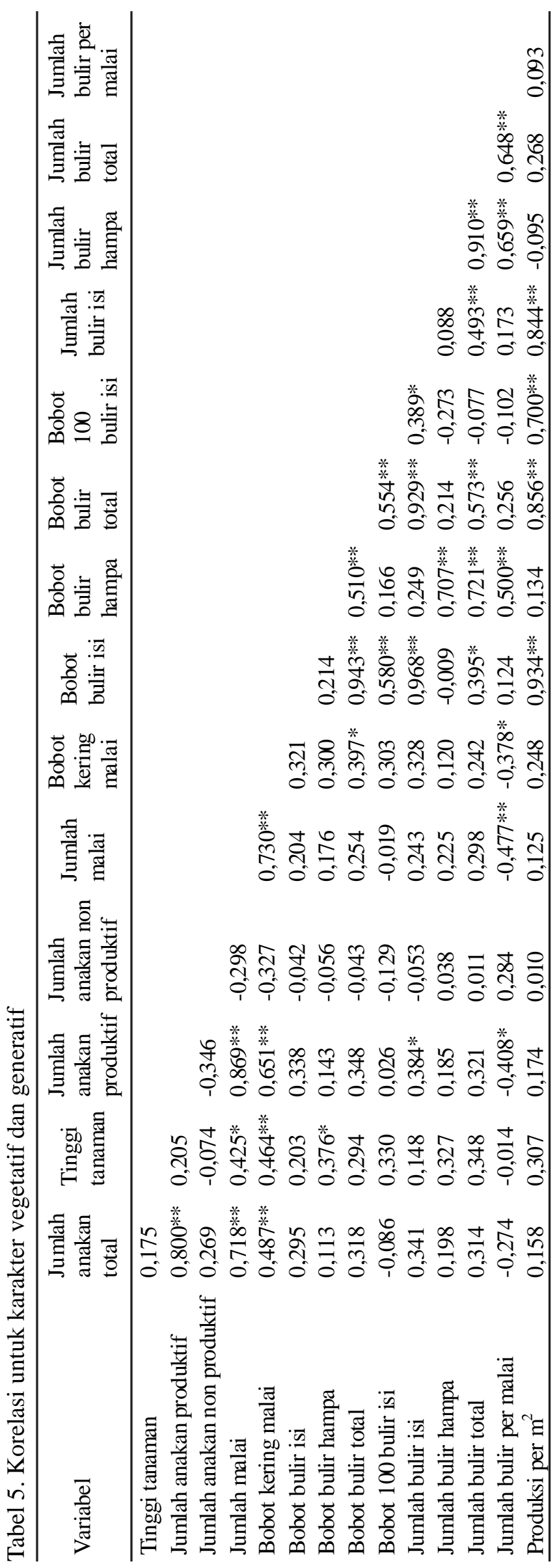

adalah jumlah bulir total yang berkorelasi dengan jumlah bulir isi, bobot bulir total dan bobot bulir isi. Korelasi antara seluruh peubah seleksi tersebut mempengaruhi produksi per $\mathrm{m}^{2}$, sehingga dapat digunakan sebagai peubah seleksi tidak langsung.Meskipun dalam penentuan seleksi ini yang digunakan bukanlah karakter vegetatif tetapi karakter generatif, yaitu jumlah bulir total. Namun, karakter ini memenuhi kriteria lain yang dapat digunakan sebagai seleksi tidak langsung dan berpengaruh terhadap produksi per $\mathrm{m}^{2}$. Sehingga digunakanlah karakter jumlah bulir total sebagai peubah seleksi tidak langsung. Peubah ini mudah diamati dengan melihat banyak atau tidaknya jumlah bulir total pada tiap rumpun dan tidak perlu menunggu sampai waktu panen tiba.

\section{KESIMPULAN}

Berdasarkan hasil penelitian yang telah dilakukan, maka dapat disimpulkan: (1) semua peubah yang diamati mampu memberikan perbedaan ragam genetik dan heritabilitas broad-sense meskipun memiliki koefisien keragaman yang cukup tinggi dan di tanam pada lingkungan gogo, (2) varietas Sarinah jumlah bulir dan Sarinah jumlah anakan dapat dijadikan sebagai salah satu tetua untuk perakitan padi inbrida dan hibrida, dan (3) korelasi yang menunjukkan peningkatan pada produksi per meter ditunjukkan dengan fenotipe jumlah bulir total, sehingga jumlah bulir total dapat digunakan sebagai peubah pada seleksi tidak langsung

\section{UCAPAN TERIMA KASIH}

Penelitian ini dibiayai oleh Penelitian Hibah Bersaing IM-HERE. Terima kasih kepada Ir. Denny Sudrajat, M.P., yang telah mengijinkan saya untuk bergabung dan membantu dalam penelitian ini.

\section{PUSTAKA ACUAN}

Bahar, H., dan S. Zen. 1999. Kriteria seleksi tanaman jagung. Jurnal Agrotropika 4(1):55 - 60.

Barus, Junita. 2012. Pengaruh aplikasi pupuk kandang dan sistim tanam terhadap hasil varietas unggul padi gogo pada lahan kering masam di lampung. bptp lampung.Jurnal Lahan Suboptimal 1(1): 102-106.

Hikam, S. 2010. Teknik Perancangan dan Analisis Pemuliaan Tanaman.Universitas Lampung. Bandar Lampung. (dalam persiapan). 
Hikam, S. 2011. Pemanfaatan galur murni tersegregasi transgresif di dalam perakitan padi non-hibrida dan hibrida yang tahan tanah asam podsolik merah kuning. Proposal Penelitian. Universitas Lampung. Hlm $1-8$.

Mulyani, A. 2006. Perkembangan potensi lahan kering masam. Balai Besar Penelitian dan Pengembangan Sumberdaya Lahan Pertanian.

Ramadhana, R. 2013. Evaluasi fenotipe quantitative trait loci (QTL) yang tersegregasi transgresif pada padi varietas Lokal di lingkungan sawah baru. Skripsi. Universitas Lampung.

Rahayu, A.T., dan T. Harjoso. 2010. Karakter agronomis dan fisiologis padi gogo yang ditanam pada media tanah bersekam pada kondisi air di bawah kapasitas lapang. Akta Agrosia. 13(1): 40 - 49.
Saputri, T.Y., S. Hikam, dan P.B. Timotiwu. 2013. Pendugaan komponen genetik, daya gabung dan segregasi biji pada jagung manis kisut. Jurnal Agrotek Tropika. 1(1):25-31.

Suprayogi, L. 2011. Evaluasi plasma nutfah padi yang tersegregasi transgresif sebagai tetua inbred pada perakitan padi hibrida dan inbrida. Skripsi. Universitas Lampung.

Suwantike, I.K.T. 2011. Evaluasi fenotipe QTL 6 varietas padi tersegregasi transgresif untuk koleksi plasma nutfah pada perakitan padi inbrida. Skripsi. Universitas Lampung. 